\title{
EFEKTIVITAS PEMBELAJARAN DARING MENGGUNAKAN MEDIA ONLINE SELAMA PANDEMI COVID-19 PADA MATA PELAJARAN MATEMATIKA
}

\section{THE EFFECTIVENESS OF E-LEARNING USING ONLINE MEDIA DURING THE COVID-19 PANDEMIC IN MATHEMATICS}

\author{
Mustakim \\ SMA Negeri 1 Wajo, Sulawesi Selatan \\ mustakin.takima@gmail.com
}

\begin{abstract}
Abstrak
Penelitian ini bertujuan untuk mengetahui gambaran efektivitas pembelajaran daring menggunakan media online selama pandemi covid-19 pada mata pelajaran matematika. Penelitian ini merupakan penelitian kuantitatif deskriptif yang fokus pada evaluasi pembelajaran menggunakan media online. Populasi penelitian yakni seluruh peserta didik SMA Negeri 1 Wajo yang diajar pada mata pelajaran matematika menggunakan metode daring. Sampel penelitian yakni peserta didik kelas XI MIPA 1 SMA Negeri 1 Wajo yang dipilih menggunakan teknik simple random sampling dengan mempertimbangkan homogenitas populasi. Instrumen pengumpulan data menggunakan kuesioner pembelajaran daring. Analisis data menggunakan statistik deskriptif. Hasil penelitian menggambarkan peserta didik menilai pembelajaran matematika menggunakan media online sangat efektif $(23,3 \%)$, sebagian besar mereka menilai efektif $(46,7 \%)$, dan menilai biasa saja (20\%). Meskipun ada juga peserta didik yang menganggap pembelajaran daring tidak efektif $(10 \%)$, dan sama sekali tidak ada $(0 \%)$ yang menilai sangat tidak efektif. Akhirnya, untuk meningkatkan kualitas pembelajaran daring matematika selama pandemi covid-19, maka pendidik harus memenuhi sepuluh saran dari responden, yakni: (1) pembelajaran dilakukan melalui video call; (2) pemberian materi pembelajaran yang ringkas; (3) meminimalisir mengirim materi dalam bentuk video berat untuk menghemat kuota; (4) pemilihan materi dalam video harus berdasarkan kriteria bahasa yang mudah dipahami; (5) tetap memberikan materi sebelum penugasan; (6) pemberian soal yang variatif dan berbeda tiap peserta didik; (7) pemberian tugas harus disertakan cara kerjanya; (8) memberikan tugas sesuai dengan jadwal pelajaran; (9) mengingatkan peserta didik jika ada tugas yang diberikan; dan (10) mengurangi tugas.
\end{abstract}

Kata Kunci: media online; pembelajaran daring, pandemi covid-19

\begin{abstract}
This study aims to describe the effectiveness of online learning during the covid-19 pandemic in mathematics. This descriptive quantitative research focuses on the evaluation of online learning. The population of this study was all the students of SMA Negeri 1 Wajo who were taught mathematics. The research sample is XI MIPA SMA Negeri 1 Wajo was selected randomly with population homogeneity consideration. Data was collected by using an online learning questionnaire and analyzed descriptively. The result showed the presentation on students' who were assuming learning mathematics was very effective with online learning was $23.3 \%$, the majority of students who assumed it was effective was 46.7 $\%, 20 \%$ of them assume it was nothing special, $10 \%$ assume it was not effective, and 0\% assume it was very ineffective. It also found from the study that to enhance the quality of mathematics online learning during the covid-19 pandemic, the teachers should full fill the respondent recommendations, they are; (1) the learning should be done with video call (2)
\end{abstract}


the contents should be simple; (3) minimize the learning video capacity (4) the language that used in the video should be easy to understand; (5) the content should be explained before giving the task; (6) variety task for each student; (7) the task should come with clear instructions; (8) the task should be on schedule; (9) the task should be reminded to the students; (10) reduces the task.

Keywords: online media, e-learning, covid-19 pandemic

How to Cite: Mustakim. (2020). Efektivitas pembelajaran daring menggunakan media online selama pandemi covid-19 pada mata pelajaran matematika. Al asma: Journal of Islamic Education, 2(1), 1-12.

\section{PENDAHULUAN}

Adanya pandemi Covid-19 melanda seluruh negeri di belahan dunia termasuk Indonesia. Sesuai data terbaru dari World Health Organization (WHO) tanggal 24 April 2020, sebanyak 213 negara telah terjangkit Covid-19, 2.631 .839 diantaranya terkonfirmasi positif dan 182.100 meninggal dunia. Covid-19 merupakan penyakit menular, yang berarti dapat menyebar, baik secara langsung maupun tidak langsung, dari satu orang ke orang lain. Kondisi ini menyerang sistem pernapasan seperti hidung, tenggorokan, dan paru-paru. Rumitnya penanganan wabah, belum ditemukannya vaksin dan obat untuk penyembuhan pasien Covid-19 serta terbatasnya alat pelindung diri (APD) untuk tenaga kesehatan membuat pemerintah menerapkan kebijakan ketat untuk memutus rantai penyebaran Covid-19.

Salah satu cara untuk memutus mata rantai penyebaran Covid-19 adalah dengan melakukan pembatasan interaksi masyarakat yang diterapkan dengan istilah physical distancing. Namun, kebijakan physical distancing tersebut dapat menghambat laju pertumbuhan dalam berbagai bidang kehidupan, baik bidang ekonomi, sosial, dan tentu saja pendidikan. Keputusan pemerintah untuk meliburkan para peserta didik, memindahkan proses belajar mengajar di sekolah menjadi di rumah dengan menerapkan kebijakan Work From Home (WFH) membuat resah banyak pihak.

WFH adalah singkatan dari work from home yang berarti bekerja dari rumah. Kebijakan WFH tertuang dalam Surat Edaran Menteri Pendayagunaan Aparatur Negara dan Reformasi Birokrasi (PAN \& RB) Nomor 50/2020 tentang Perubahan Kedua atas Surat Edaran Menteri PAN \& RB Nomor 19/2020 tentang Penyesuaian Sistem Kerja Aparatur Sipil Negara dalam Upaya Pencegahan Penyebaran Covid-19 di Lingkungan Instansi Pemerintah. Sebagai ASN, guru dalam upaya melaksanakan proses pembelajaran perlu dilakukan secara online atau dalam jaringan (daring). Namun, pelaksanaan proses pembelajaran secara online memiliki beberapa kendala. Salah satu kendala terberat dalam pembelajaran daring adalah mengajar mata pelajaran matematika.

Problematika saat ini adalah masih banyak peserta didik yang menganggap matematika pelajaran yang sulit. Sebagaimana pendapat Auliya (2016), matematika dianggap sebagai pelajaran yang sulit karena karakteristik matematika yang bersifat abstrak, logis, sistematis, dan penuh dengan lambang serta rumus yang membingungkan. Kesulitan yang ada dalam mata pelajaran matematika menuntut kreativitas guru mata pelajaran matematika untuk mengembangkan pembelajarannya, baik dalam hal metode maupun media yang digunakan. 
Penggunaan media online atau media berbasis multimedia merupakan salah satu solusi untuk membuat peserta didik mampu memahami materi pelajaran dengan baik. Hal ini sejalan dengan hasil penelitian Ibrahim \& Suardiman (2014) yang menunjukkan bahwa ada pengaruh positif penggunaan e-learning terhadap motivasi dan prestasi belajar peserta didik di SD Negeri Tahunan Yogyakarta. Pembelajaran daring menggunakan media online telah diterapkan di SMA Negeri 1 Wajo sejak mulai diberlakukannya work from home pada 16 Maret 2020 selama masa pandemi covid-19. Media online yang digunakan seperti youtube, whatsapp group, google classroom, dan quizzes. Materi diberikan dalam bentuk powerpoint, video singkat, dan bahan bacaan. Namun dalam pelaksanaan pembelajaran daring tersebut, perlu dilakukan evaluasi agar didapatkan langkah perbaikan jelas yang berbasis data. Hal itulah yang mendasari penulis untuk mengetahui gambaran efektivitas pembelajaran daring menggunakan media online pada mata pelajaran matematika kelas XI MIPA 1 SMA Negeri 1 Wajo.

\section{METODE PENELITIAN}

Penelitian ini merupakan penelitian kuantitatif deskriptif untuk mengetahui gambaran efektivitas pembelajaran daring menggunakan media online pada mata pelajaran matematika. Populasi penelitian yakni seluruh peserta didik SMA Negeri 1 Wajo yang diajar mata pelajaran matematika menggunakan metode daring. Sampel yang menjadi responden penelitian ini yakni sebanyak 30 peserta didik kelas XI MIPA 1 SMA Negeri 1 Wajo yang dipilih menggunakan teknik simple random sampling dengan mempertimbangkan homogenitas populasi. Instrumen pengumpulan data menggunakan kuesioner yang berisi jenis pertanyaan tertutup, semi tertutup, dan terbuka yang dibagikan menggunakan google form. Analisis data menggunakan statistik deskriptif dengan bantuan komputerisasi.

\section{HASIL DAN PEMBAHASAN}

\section{Karakteristik Sampel}

Jumlah sampel yang menjadi responden dalam penelitian ini sebanyak 30 peserta didik yang terdiri dari 53,3\% jenis kelamin perempuan dan $46,7 \%$ jenis kelamin laki-laki (Lihat Gambar 1). Sebagian besar responden berasal dari kecamatan Tempe (56,7\%) dan kecamatan sekitarnya, yakni Pammana (16,7\%), Sabbangparu (13,3\%), Tanasitolo $(6,7 \%)$, dan Majauleng (6,7\%). (Lihat Gambar 2).

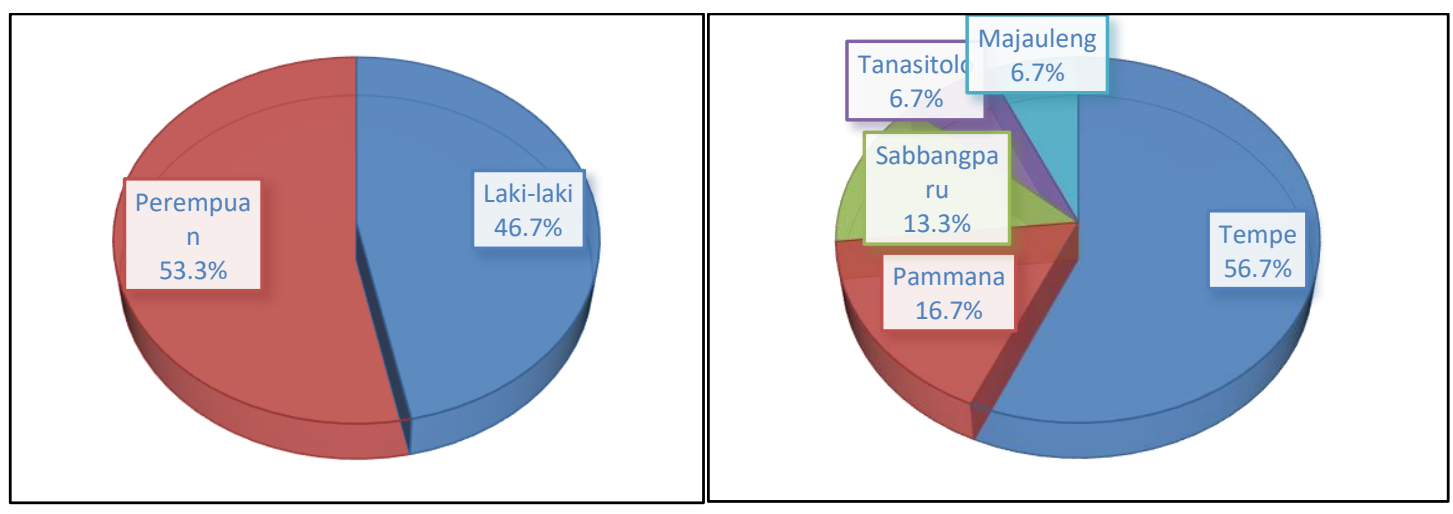

Gambar 1. Jenis Kelamin

Gambar 2. Domisili 
Domisili peserta didik yang hanya berada pada wilayah kecamatan sekolah ini telah menunjukkan bahwa sekolah ini telah mematuhi aturan dalam penerimaan peserta didik, yakni sesuai dengan lokasi tempat tinggal anak atau aturan tentang sistem zonasi. Aturan terkait sistem zonasi ini tertuang dalam Peraturan Menteri Pendidikan dan Kebudayaan (Permendikbud) Nomor 51 Tahun 2018 tentang Penerimaan Peserta Didik Baru Pada TK, SMP, SMA, dan SMK. Dalam aturan tersebut dijelaskan bahwa sekolah di bawah pemerintah atau berstatus negeri dalam proses Penerimaan Peserta Didik Baru (PPDB) wajib menerima minimal 90 persen peserta didik baru yang yang berasal dari dekat sekolah.

Selama pemberlakuan work from home ini, responden paling banyak menghabiskan waktu dalam sehari dengan mengerjakan tugas-tugas sekolah untuk semua mata pelajaran, termasuk tugas matematika. Aktivitas lain yang mereka kerjakan adalah bermain handphone. Mereka mengatakan selama WFH ini, mereka tidak bisa menahan diri bermain handphone karena dalam mengerjakan tugas mereka menggunakan handphone. Jadi, disela mengerjakan tugas itulah mereka main game, atau menggunakan media sosial untuk chatting dengan temannya. (Lihat Gambar 3).

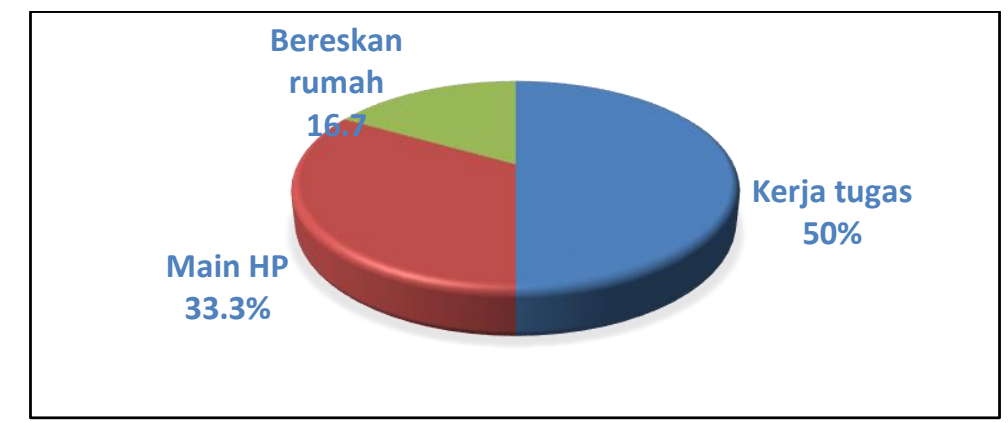

Gambar 3. Aktivitas yang Paling Banyak Dikerjakan Selama WFH

Penggunaan handphone dengan durasi yang terlalu lama dan intensitas yang terlalu sering karena digunakan mengerjakan tugas dan membuka media sosial mengakibatkan mereka mengalami keluhan fisik paling banyak berupa mata kelelahan $(53,3 \%)$. Mereka juga mengeluhkan sakit kepala $(33,3 \%)$, sering mengantuk $(33,3 \%)$, sulit istirahat $(20 \%)$, dan keluhan lainnya $(13,3 \%)$ seperti demam, sesak nafas, dan badan pegal. Meskipun demikian, sebanyak 30\% peserta didik merasa tidak ada keluhan fisik. (Lihat Gambar 4).

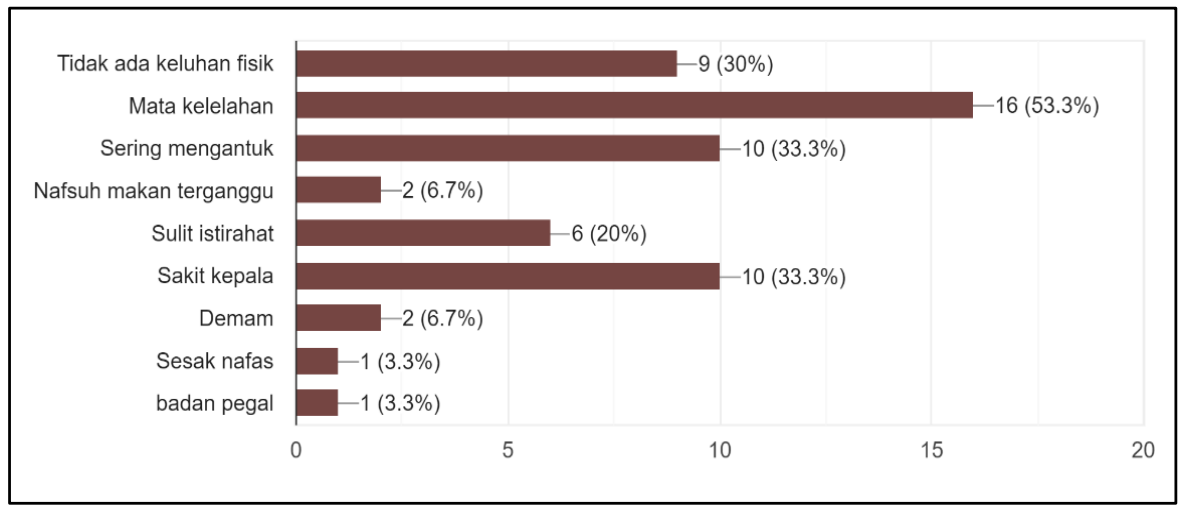


Gambar 4. Keluhan Fisik yang Dialami

Keluhan fisik tersebut merupakan dampak dari penggunaan gadget yang berlebihan. Hasil penelitian ini sesuai dengan hasil penelitian yang sebelumnya dilakukan oleh Sidabutar dkk. (2019) yang menunjukkan bahwa penggunaan gadget dapat menyebabkan sakit kepala dan iritasi mata. Menurut Ilyas dalam Bawelle dkk. (2016), mata lelah dapat terjadi jika mata fokus kepada objek berjarak dekat dalam waktu yang lama dan otot-otot mata bekerja lebih keras untuk melihat objek terutama jika disertai dengan pencahayaan yang menyilaukan.

Selain keluhan fisik, peserta didik juga mengalami keluhan psikologis. Keluhan yang paling banyak dialami yakni perasaan ingin semuanya segera berakhir $(70 \%)$, mereka juga merasakan kebosanan yang dalam (63,3\%), pusing, (20\%), khawatir (20\%), dan resah (3,3\%). Namun, ada diantara mereka yang sama sekali tidak merasakan keluhan psikologis (16,7 \%). (Lihat Gambar 5).

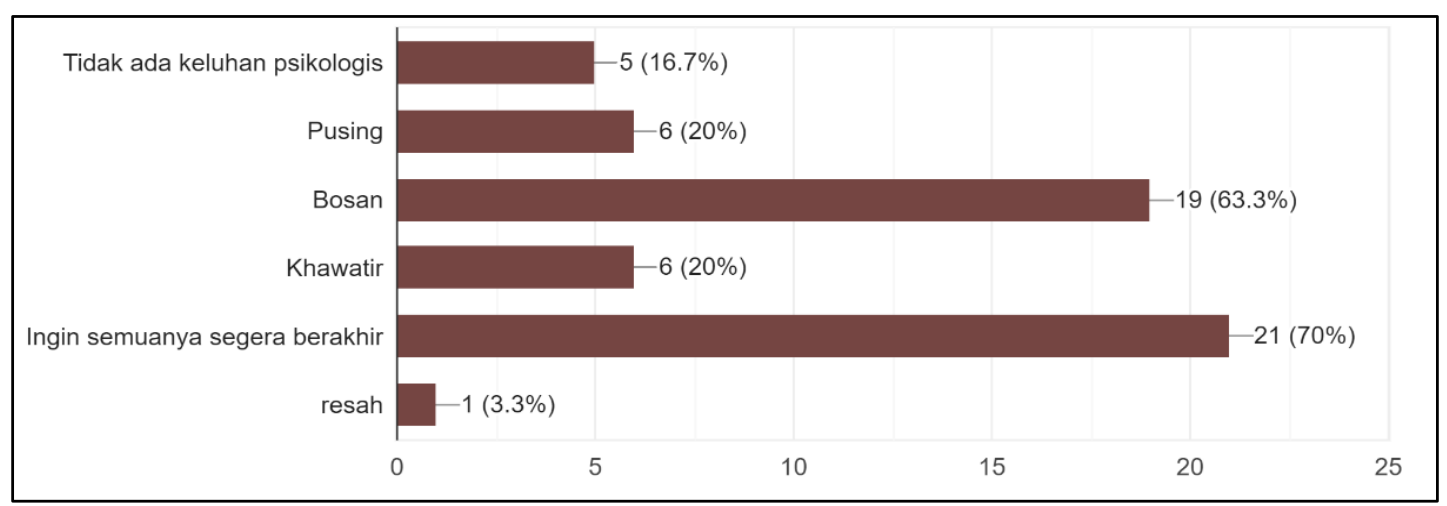

Gambar 5. Keluhan Psikologis yang Dialami Peserta Didik

\section{Gambaran tentang Pembelajaran Daring Matematika}

\section{a. Model Pembelajaran Daring yang Disukai Peserta Didik}

Hasil penelitian deskriptif menggambarkan hanya sebagian peserta didik yang menyukai pembelajaran menggunakan daring yakni sebesar $26,7 \%$, dan yang menyukai model pembelajaran blended (perpaduan tatap muka dengan daring) sebesar 26,7\%, serta sebagian besar peserta didik menyatakan menyukai pembelajaran dengan tatap muka yakni sebesar 46,6\%. (Lihat Gambar 6).

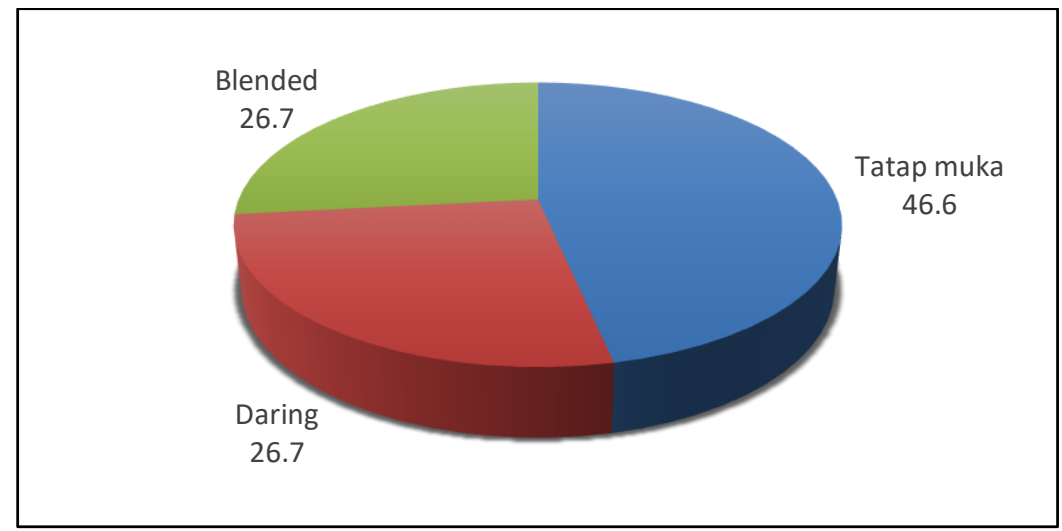

Gambar 6. Model Pembelajaran yang Disukai 
Hartanto (2016) mengungkapkan bahwa teknologi informasi dan telekomunikasi yang murah dan mudah akan menghilangkan batasan ruang dan waktu yang selama ini membatasi dunia pendidikan. Beberapa konsekuensi logis yang terjadi dalam penggunaan e-learning, antara lain (1) peserta didik dapat dengan mudah mengakses materi pembelajaran dimanapun tanpa terbatas lagi pada batasan tempat dan waktu; (2) peserta didik dapat dengan mudah berguru dan berdiskusi dengan para tenaga ahli atau pakar di bidang yang diminatinya; (3) materi pembelajaran bahkan dapat dengan mudah diambil di berbagai penjuru dunia tanpa tergantung pada dimana peserta didik belajar. Berbagai peluang tersebut masih menghadapi tantangan baik dari biaya, kesiapan infrastuktur teknologi informasi, masyarakat, dan peraturan yang mendukung terhadap kelangsungan e-learning.

Meskipun banyak kemudahan yang diberikan pembelajaran daring melalui internet, namun hasil penelitian ini menunjukkan peserta didik lebih menyukai pembelajaran tatap muka. Berdasarkan wawancara dengan psikolog pendidikan, Eva Maizarra Puspita Dewi, dikemukakan bahwa ada tiga reaksi perilaku individu ketika diperhadapkan dengan bahaya, pertama dia akan menolak kenyataan. Selanjutnya, dia akan tawar menawar, dan terakhir dia akan menerima. Mungkin saat ini peserta didik lebih menyukai pembelajaran tatap muka karena mereka masih dalam tahap menolak. Hal itu disebabkan karena baru sebulan pembelajaran daring ini berlangsung. Ada kemungkinan beberapa bulan berikut ketika peserta didik ditanyakan lagi pertanyaan yang sama, mungkin jawabannya akan berubah karena sudah mampu menyesuaikan diri dengan pembelajaran daring.

Hasil penelitian Kuntarto (2017) menunjukkan bahwa model pembelajaran daring telah memberikan pengalaman baru yang lebih menantang daripada model pembelajaran konvensional (tatap muka). Tak terbatas waktu dan tempat belajar memberikan peserta didik kebebasan untuk memilih saat yang tepat dalam pembelajaran berdasarkan kepentingan mereka, sehingga kemampuan untuk menyerap bahan pembelajaran menjadi lebih tinggi daripada belajar di dalam kelas, sedangkan hasil penelitian Wardani dkk. (2018) bahwa dengan blended learning dapat membuat peserta didik untuk lebih aktif dalam proses pembelajaran di kelas dan online, dapat membuat proses pembelajaran menjadi lebih menyenangkan. Apabila guru dapat membuat proses pembelajaran tersebut menyenangkan, maka peserta didik akan tertarik untuk mengikuti proses pembelajaran.

\section{b. Media Daring yang Paling Disukai Peserta Didik}

Media daring yang paling disukai peserta didik secara berturut turut yakni Google Classroom (53\%), WhatsApp Group (21\%), Youtube (16\%), Instagram (7\%), dan Zoom (3\%). Mereka menyukai media tersebut karena dianggap mudah dan praktis digunakan. Selain itu, karena tidak terlalu banyak menyita pulsa kuota. Meskipun demikian, mereka masih menginginkan adanya pertemuan tatap muka via online seperti youtube dan zoom sebagaimana yang mereka sarankan dalam penelitian ini. Hanya saja kendala kuota dan akses jaringan terbatas, sehingga mereka berharap pihak pemerintah menyediakan fasilitas daring yang efektif dan tidak membebani. (Lihat Gambar 7). 


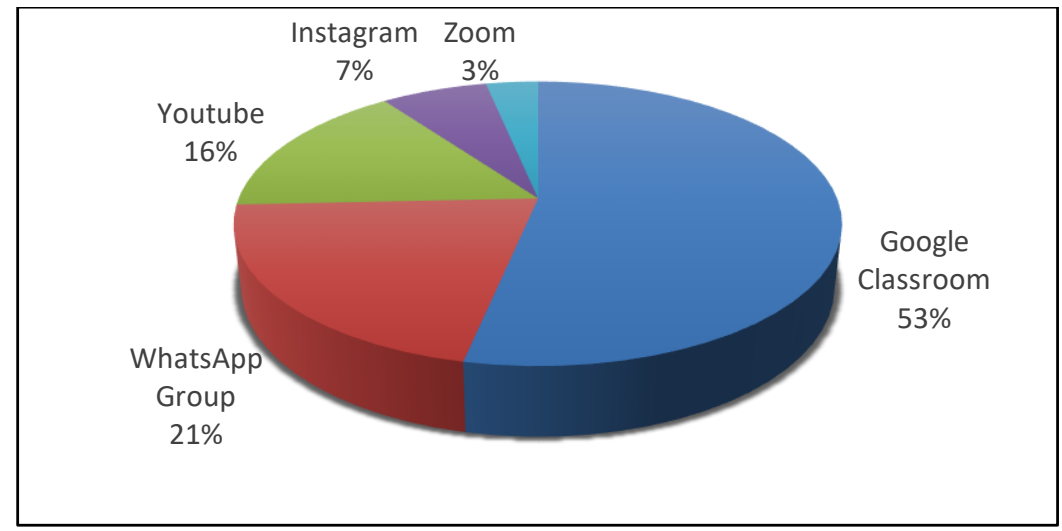

Gambar 7. Media Daring yang Disukai

Waryanto (2006) mengungkapkan bahwa keuntungan dari model pembelajaran daring adalah dapat digunakan untuk menyampaikan pembelajaran tanpa dibatasi ruang dan waktu, dapat menggunakan berbagai sumber yang sudah tersedia di internet, dan bahan ajar relatif mudah untuk diperbaharui. Selain itu, dapat meningkatkan kemandirian peserta didik dalam proses pembelajaran.

Hasil penelitian Chandrawati (2010) bahwa pengajar diharapkan dapat menyajikan materi melalui web yang menarik dan diminati, melayani bimbingan dan komunikasi melalui internet, dan kecakapan lain yang diperlukan. Hasil penelitian Hikmatiar dkk. (2020) menunjukkan bahwa penggunaan google classroom sebagai media pembelajaran memberikan dampak yang positif terhadap peningkatan hasil belajar, minat dan motivasi peserta didik dalam belajar serta menumbuhkan sikap kreatif pada peserta didik ataupun mahasiswa. Berdasarkan hasil penelitian Maharani \& Kartini (2019), google classroom dapat meningkatkan minat dan motivasi karena bahan ajar sudah lengkap tersedia di google classroom dengan fitur-fitur yang dimilikinya.

\section{c. Metode Pembelajaran yang Disukai Peserta Didik saat Daring}

Metode pembelajaran daring yang paling disukai peserta didik secara berturutturut sebagai berikut: diskusi, kuis, penugasan individu, ceramah dengan guru yang menjelaskan, video, dan penugasan kelompok. (Lihat Gambar 8).

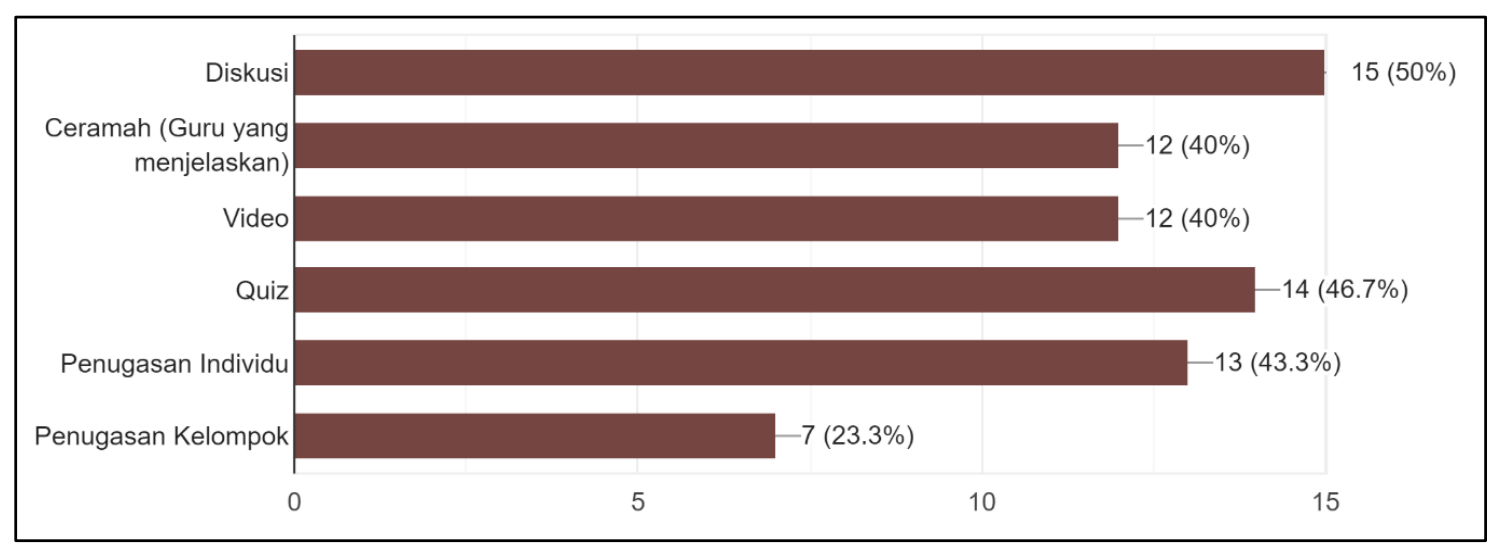

Gambar 8. Metode Pembelajaran yang Disukai Ketika Daring 
Hasil penelitian Sari, P. (2015) mengungkapkan bahwa untuk memotivasi peserta didik baik secara intrinsik maupun ekstrinsik, penggunaan e-learning dalam proses pembelajaran harus memperhatikan prinsip-prinsip penggunaan serta kelebihan dan kekurangan e-learning. Proses pembelajaran dengan menggunakan e-learning hendaknya tidak menempatkan peserta didik hanya sebagai "pendengar" atau "penonton" saja, melainkan juga mendorong partisipasi aktif dari peserta didik untuk berinteraksi, berdialog, bekerja sama, berbagi dan membangun pengetahuan bersama. Selain itu, dalam menggunakan e-learning guru harus kreatif dan inovatif serta memiliki sikap kritis dalam memilih bahan pembelajaran, beretika baik dalam memanfaatkan bahan tersebut, menghindari penggunaan gambar- gambar atau audio yang kurang relevan dengan materi pembelajaran, mendorong partisipasi aktif dari peserta didik, memberikan perhatian dan menyediakan waktu lebih terhadap peserta didik tidak terbatas pada saat tatap muka di kelas, sabar membimbing peserta didik yang mengalami kesulitan dalam menggunakan elearning, profesional serta memiliki motivasi untuk terus belajar dan meningkatkan pengetahuan dan keterampilan.

Hasil penelitian Hanum (2013) bahwa interaksi pembelajaran dapat berjalan apabila terdapat pengelola pembelajaran (guru), sumber belajar, subjek pembelajar, interaksi antara pengajar/guru. Pengelolaan pembelajaran dapat dilakukan oleh guru, sehingga guru memberikan peran aktif dalam sistem pembelajaran termasuk dalam $e$ learning. Hasil penelitian Yazdi (2012) menunjukkan bahwa melalui metode diskusi/forum, guru dan peserta didik dapat melakukan interaksi secara langsung sehingga memudahkan peserta didik dalam proses pembelajaran ketika daring.

\section{d. Kendala yang Dihadapi Peserta Didik Selama Daring}

Kendala yang dihadapi peserta didik selama pembelajaran daring, yakni jaringan internet tidak stabil, tugas terlalu banyak, sulit fokus, pulsa kuota terbatas, aplikasi yang rumit, dan lebih senang dengan pembelajaran tatap muka. (Lihat Gambar 9).

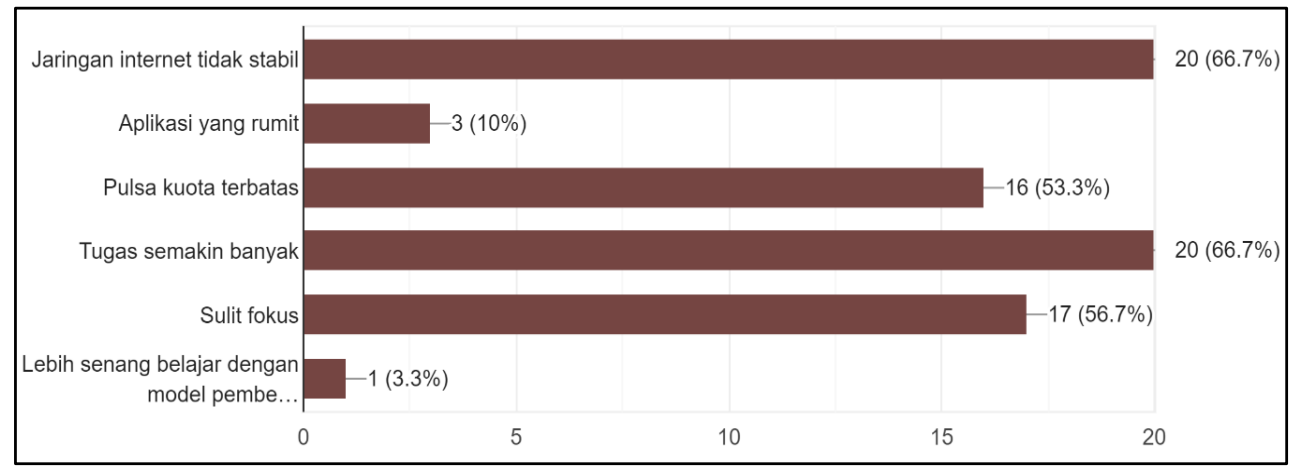

Gambar 9. Kendala yang Dihadapi Selama Daring

Hasil penelitian Hendrastomo (2008) bahwa ketersediaan akses internet sangat diperlukan dalam pembelajaran e-learning, karena karakteristik pembelajaran ini selalu menggunakan dan memanfaatkan jaringan internet. Secara umum, kecepatan akses jaringan internet di Indonesia relatif lambat, ketersediaan jaringan internet yang masih terbatas dan harga untuk mengakses internet relatif mahal sehingga menjadi hambatan bagi pembelajaran e-learning. 


\section{e. Penilaian Keefektifan Pembelajaran Daring}

Peserta didik menerima kenyataan bahwa saat ini sedang diberlakukan work from home yang menuntut untuk dilakukan pembelajaran daring. Peserta didik menilai pembelajaran matematika menggunakan media online sangat efektif $(23,3 \%)$, sebagian besar mereka menilai efektif $(46,7 \%)$, dan menilai biasa saja (20\%). Meskipun ada juga peserta didik yang menganggap pembelajaran daring tidak efektif $(10 \%)$. (Lihat Gambar 10).

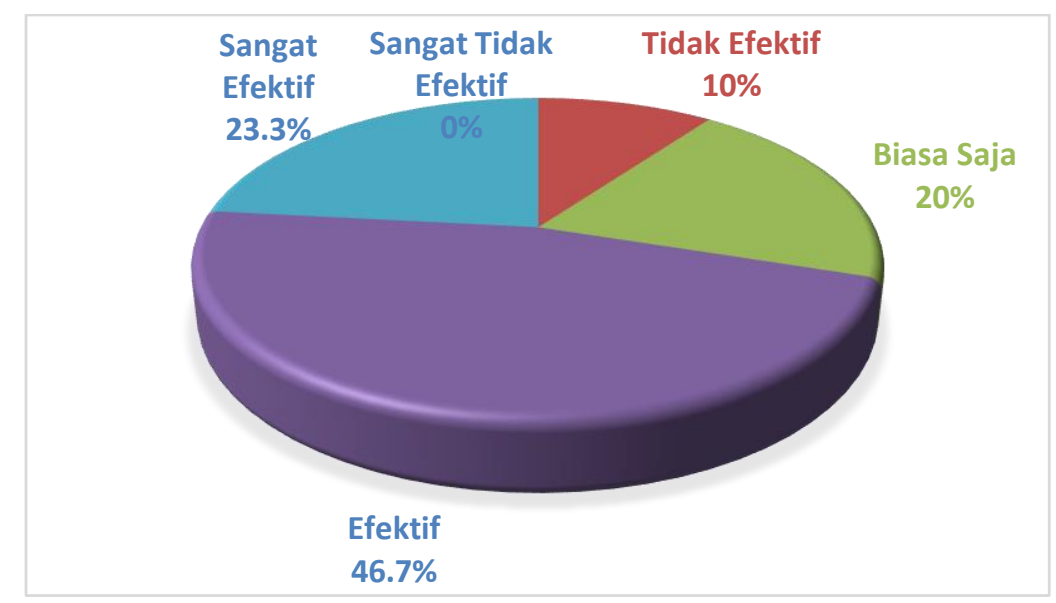

Gambar 10. Penilaian Keefektifan Pembelajaran Daring

Penggunaan media online dalam pembelajaran daring memungkinkan peserta didik untuk memiliki semangat yang tinggi untuk belajar dan mengerjakan tugas. Hasil penelitian Sianturi (2018) menunjukkan bahwa penggunaan internet pada mahasiswa secara signifikan dapat memengaruhi motivasi mahasiswa dalam menggunakan $e$ learning.

Hasil penelitian Puspitasari dkk. (2018) menunjukkan bahwa terdapat pengaruh yang signifikan penggunaan media pembelajaran terhadap motivasi peserta didik. Begitu pula dengan hasil penelitian yang dilakukan oleh Ibrahim \& Suardiman (2014) bahwa ada pengaruh positif penggunaan e-learning terhadap motivasi dan prestasi belajar peserta didik di SD Negeri Tahunan Yogyakarta. Hasil penelitian Aurora \& Effendi (2019) juga menunjukkan bahwa terdapat pengaruh yang positif dan signifikan antara penggunaan media pembelajaran e-learning dengan motivasi belajar mahasiswa. Hasil penelitian Nadziroh (2017) bahwa e-learning efektif dalam meningkatkan mutu pembelajaran, karena proses pembelajaran tidak hanya terpaku dalam satu waktu dan dalam ruangan saja.

\section{f. Saran agar Pembelajaran Matematika Lebih Efektif}

Terdapat 10 saran yang diberikan oleh sampel penelitian supaya pembelajaran matematika kedepannya jauh lebih efektif, yakni:

1) Pembelajaran dilakukan melalui video call;

2) Pemberian materi pembelajaran yang ringkas;

3) Meminimalisir mengirim materi dalam bentuk video berat untuk menghemat kuota; 
4) Pemilihan materi dalam video harus berdasarkan kriteria bahasa yang mudah dipahami;

5) Tetap memberikan materi sebelum penugasan;

6) Pemberian soal yang bervariatif dan berbeda tiap peserta didik;

7) Pemberian tugas harus disertakan cara kerjanya;

8) Memberikan tugas sesuai dengan jadwal pelajaran;

9) Mengingatkan peserta didik jika ada tugas yang diberikan;

10) Mengurangi tugas.

Meskipun peserta didik lebih banyak menyukai pembelajaran secara tatap muka, namun mereka menerima kenyataan pembelajaran daring sebagai konsekuensi pemberlakuan work from home dari pemerintah. Hal tersebut membuat mereka semakin sering dan semakin lama menggunakan handphone untuk daring dan untuk mengerjakan tugas pelajaran. Hal itu juga yang membuat mereka mengalami keluhan fisik terbanyak seperti mata kelelahan dan sakit kepala. Begitu pula dengan keluhan psikologis bahwa ingin semuanya segera berakhir.

\section{SIMPULAN}

Inovasi pembelajaran yang dilakukan oleh guru matematika yakni dengan menggunakan media online membantu peserta didik menjalani pembelajaran daring selama pandemi covid-19 ini. Alhasil, peserta didik menilai pembelajaran matematika menggunakan media online sangat efektif $(23,3 \%)$, sebagian besar mereka menilai efektif (46,7\%), dan menilai biasa saja (20\%). Meskipun ada juga peserta didik yang menganggap pembelajaran daring tidak efektif $(10 \%)$, dan sama sekali tidak ada $(0 \%)$ yang menilai sangat tidak efektif. Untuk membuat pembelajaran matematika lebih efektif lagi, kedepannya guru atau pendidik diharapkan menerapkan sepuluh saran yang diberikan peserta didik, yakni (1) pembelajaran dilakukan melalui video call; (2) pemberian materi pembelajaran yang ringkas; (3) meminimalisir mengirim materi dalam bentuk video berat untuk menghemat kuota; (4) pemilihan materi dalam video harus berdasarkan kriteria bahasa yang mudah dipahami; (5) tetap memberikan materi sebelum penugasan; (6) pemberian soal yang bervariatif dan berbeda tiap peserta didik; (7) pemberian tugas harus disertakan cara kerjanya; (8) memberikan tugas sesuai dengan jadwal pelajaran; (9) mengingatkan peserta didik jika ada tugas yang diberikan; dan (10) mengurangi tugas.

\section{DAFTAR PUSTAKA}

Auliya, R. N. (2016). Kecemasan Matematika dan Pemahaman Matematis. Formatif: Jurnal Ilmiah Pendidikan MIPA, 6(1), 12-22. https://doi.org/10.30998/formatif.v6i1.748.

Aurora, A., \& Effendi, H. (2019). Pengaruh Penggunaan Media Pembelajaran E-learning terhadap Motivasi Belajar Mahasiswa di Universitas Negeri Padang. JTEV (Jurnal Teknik Elektro Dan Vokasional), 05(02), 11-16.

Bawelle, C. F. N., Lintong, F., \& Rumampuk, J. (2016). Hubungan penggunaan smartphone dengan fungsi penglihatan pada mahasiswa Fakultas Kedokteran Universitas Sam Ratulangi Manado angkatan 2016. Jurnal E-Biomedik, 4(2), 0-5. https://doi.org/10.35790/ebm.4.2.2016.14865.

Chandrawati, S. R. (2010). Pemanfaatan e-learning dalam pembelajaran. Jurnal Cakrawala Pendidikan, 8(2), 172-181. 
Hanum, N. S. (2013). Keefetifan e-learning sebagai media pembelajaran (studi evaluasi model pembelajaran e-learning SMK Telkom Sandhy Putra Purwokerto). Jurnal Pendidikan Vokasi, 3(1), 90-102. https://doi.org/10.21831/jpv.v3i1.1584.

Hartanto, W. (2016). Penggunaan E-Learning sebagai Media Pembelajaran. Jurnal Pendidikan Ekonomi, 10(1), 1-18.

Hendrastomo, G. (2008). Dilema dan Tantangan Pembelajaran E-learning 1 (The Dilemma and the Challenge of. Majalah Ilmiah Pembelajaran, 4, 1-13.

Hikmatiar, H., Sulisworo, D., \& Wahyuni, M. E. (2020). Pemanfaatan Learning Manegement System Berbasis Google Classroom Dalam Pembelajaran. Jurnal Pendidikan Fisika, 8(1), 78-86. https://doi.org/10.26618/jpf.v8i1.3019.

Ibrahim, D. S., \& Suardiman, S. P. (2014). Pengaruh Penggunaan E-Learning Terhadap Motivasi Dan Prestasi Belajar Matematika Siswa Sd Negeri Tahunan Yogyakarta. Jurnal Prima Edukasia, 2(1), 66. https://doi.org/10.21831/jpe.v2i1.2645.

Kuntarto, E. (2017). Keefektifan Model Pembelajaran Daring dalam Perkuliahan Bahasa Indonesia di Perguruan Tinggi. Journal Indonesian Language Education and Literature, 3(1), 53-65.

Maharani, N., \& Kartini, K. S. (2019). Penggunaan google classroom sebagai pengembangan kelas virtual dalam keterampilan pemecahan masalah topik kinematika pada mahasiswa jurusan sistem komputer. PENDIPA Journal of Science Education, 3(3), 167-173. https://doi.org/10.33369/pendipa.3.3.167-173.

Nadziroh, F. (2017). Analisa Efektifitas Sistem Pembelajaran Berbasis E-Learning. Jurnal Ilmu Komputer Dan Desain Komunikasi Visual (Jikdiskomvis), 2(1), 1-14.

Surat Edaran Menteri Pendayagunaan Aparatur Negara dan Reformasi Birokrasi (PAN \& RB) Nomor 50/2020 tentang Perubahan Kedua atas Surat Edaran Menteri PAN \& RB Nomor $19 / 2020$.

Peraturan Menteri Pendidikan dan Kebudayaan (Permendikbud) Nomor 51 Tahun 2018 tentang Penerimaan Peserta Didik Baru Pada TK, SMP, SMA, dan SMK.

Puspitasari, P., Sari, P., Putri, J., \& Wuryani, W. (2018). Pengaruh Penggunaan Media Pembelajaran terhadap Motivasi Belajar Mahasiswa IKIP Siliwangi. Parole: Jurnal Pendidikan Bahasa Dan Sastra Indonesia, 1(2), 227-232. https://doi.org/http://dx.doi.org/10.22460/p.v1i2p\%25p.243.

Sari, P. (2015). Memotivasi Belajar Dengan Menggunakan E-Learning. Ummul Quro, 6(2), 20-35.

Sianturi, S. R. (2018). Meningkatkan Motivasi Belajar Melalui Evaluasi E-Learning Pada Institusi Keperawatan Di Jakarta Dan Depok. Jurnal Pendidikan Keperawatan Indonesia, 4(2). https://doi.org/10.17509/jpki.v4i2.11563.

Sidabutar, L., Adhitya, T., Wong, F., Rici, M., \& Wibisono, Y. P. (2019). Analisis Pengaruh Game Online Mobile Terhadap Kesehatan Mata Pada Mahasiswa FTI UAJY. Sintak 2019, 3, 402-410.

Surat Edaran Menteri Pendayagunaan Aparatur Negara dan Reformasi Birokrasi (PAN \& RB) Nomor 50/2020.

Wardani, D. N., Toenlioe, A. J. E., \& Wedi, A. (2018). Daya Tarik Pembelajaran di Era 21 Dengan Blended Learning. Jurnal Kajian Teknologi Pendidikan (JKTP), 1(1), 13-18. 
Waryanto, N. H. (2006). On-line Learning Sebagai Salah Satu Inovasi Pembelajaran. Pythagoras, 2(1), 10-23.

Yazdi, M. (2012). E-learning sebagai Media Pembelajaran Interaktif Berbasis teknologi Informasi. Jurnal Ilmiah Foristek, 2(1), 143-152. 